\title{
COMPLEXATION OF NANOSCALE ENZYME INHIBITOR WITH CARBONIC ANHYDRASE ACTIVE CENTER: A QUANTUM MECHANICAL APPROACH
}

\author{
M. Ghiasi ${ }^{1}$, S. Kamalinahad ${ }^{1}$, and M. Zahedi ${ }^{2}$
}

UDC 541.6:547.13:546:47

The complex between carbonic anhydrase enzyme center (CA) and a derivative of fullerene as a nanoscale inhibitor (C60-Inh) has been investigated, based on, B3LYP level, using 6-31G* basis set. The results of calculations indicate that this special fullerene derivative could be deprotonated from three different positions and interacts with CA active site to form three CA-C60-Inh complexes. The calculated results indicate that deprotonated inhibitor is coordinated to the $\mathrm{Zn}^{2+}$ ion and all the complexes have tetrahedral geometry. The calculated binding energy (BD) and complexation energy clearly show the complex between C60-Inh and CA active site from N13 position is more favorable than the other position. Also thermodynamic functions such as standard enthalpy of complexation $\left(\Delta H_{\text {com }}^{0}\right)$, standard entropy of complexation $\left(\Delta S_{\text {com }}^{0}\right)$ and standard Gibbs free energy of complexation $\left(\Delta G_{\mathrm{com}}^{0}\right)$ for three CA-inhibitor complexes are evaluated. In order to approach the ideal geometry and provide further insight into the different complexation properties, the single point calculation at the B3LYP/6-311G** level have been used for all three different complexes to confirm the results of B3LYP/6-31G*. Thus, fullerene derivatives show a new class of nano scale carbonic anhydrase inhibitors that might find applications for targeting physiologically relevant isoforms of different forms of CA.

DOI: $10.1134 / \mathrm{S} 0022476614080277$

Keywords: carbonic anhydrase, fullerene, inhibitor, complexation energy, QM calculation.

\section{INTRODUCTION}

Several carbonic anhydrase (CA, EC 4.2.1.1) isoforms are known to be present in the vertebrate central nervous system (CNS), being located in various cell populations, where they play a variety of functions $[1,2]$. In all enzyme classes, a metal hydroxide species $\left(\mathrm{L}_{3}-\mathrm{M}^{2+}-\mathrm{OH}^{-}\right)$of the enzyme is the catalytically active species [3]. The active center normally comprises $\mathrm{M}(\mathrm{II})$ ions in tetrahedral geometry, with three protein ligands (L) in addition to the water molecule/hydroxide ion [4], Fig. 1. CAs are mostly zinc-metalloenzymes that are structurally classified into five families: $\alpha, \beta, \gamma, \delta$, and $\varepsilon$. The $\alpha-$ class of CA, which includes human carbonic anhydrase II (HCA II), has been extensively characterized. HCA II catalyzed the reversible, two-step conversion of carbon dioxide to a bicarbonate ion and an excess proton via the "ping-pong" mechanism [5-12].

${ }^{1}$ Department of Chemistry, Faculty of Science, Alzahra University, 19835-389, Vanak, Tehran, Iran; ghiasi@alzara.ac.ir. ${ }^{2}$ Department of Chemistry, Faculty of Science, Shahid Beheshti University, G. C., Evin, 19839-63113, Tehran, Iran. The text was submitted by the authors in English. Zhurnal Strukturnoi Khimii, Vol. 55, Supplement 2, pp. S392S403, 2014. Original article submitted April 30, 2013. 


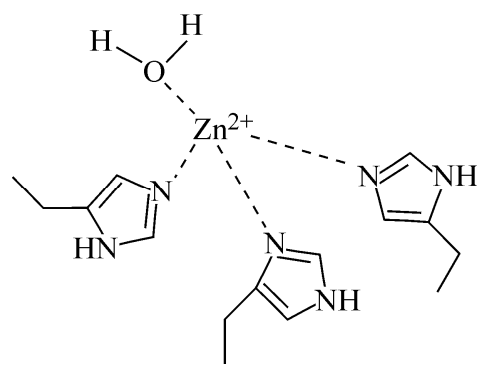

Fig. 1. Chemical structure of carbonic anhydrase (CA) enzyme.

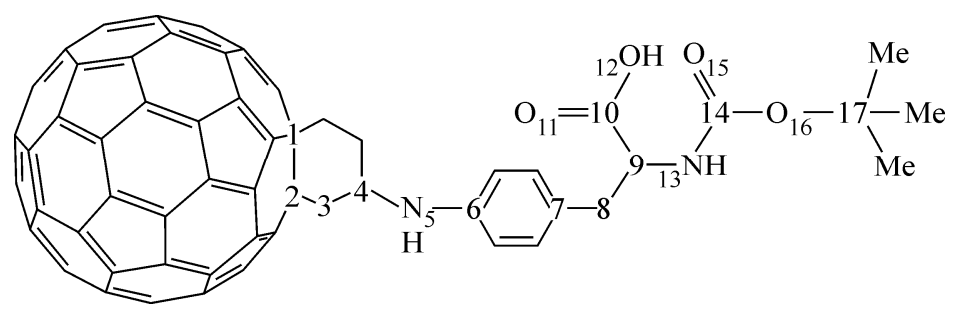

Fig. 2. Chemical structure of the nanoscale inhibitor $\left(\mathrm{C}_{60}-\mathrm{Inh}\right)$.

These enzymes are also involved in electrolyte secretion in a variety of tissues and in many biosynthetic reactions, such as gluconeogenesis, lipogenesis, ureagenesis, bone resorption, calcification, tumorigenicity, and many other physiological or pathological processes [13]. CAs are important targets for the design of novel pharmacological agents useful in the treatment or prevention of a variety of disorders, such as glaucoma, acid-base disequilibria, epilepsy, other neuromuscular diseases, as well as altitude sickness and obesity $[13,14]$. The inhibition and activation of CAs are also wellunderstood processes, with most classes of inhibitors binding to the metal center [13, 15-19].

One main class of CA inhibitors (CAIs) is known as the metal complexing anions which bind to the $\mathrm{Zn}$ (II) ion of the enzyme by substituting the non-protein zinc ligand, Eq. 1, generating tetrahedral geometry of the $\mathrm{Zn}(\mathrm{II})$ ion. Thus, the CAinhibitor interaction constitutes the initial stage of the mechanism of inhibitors action.

$$
\left[\mathrm{E}-\mathrm{Zn}-\mathrm{OH}_{2}\right]^{2+}+\mathrm{I}^{-} \text {(inhibitor anion) } \leftrightarrow[\mathrm{E}-\mathrm{Zn}-\mathrm{I}]^{+}+\mathrm{H}_{2} \mathrm{O} \text {. }
$$

In this way, the nanomaterial fullerene $\mathrm{C}_{60}[20,21]$ and its derivatives have exhibited many interesting activities in biomedical application, such as antitumor photodynamic therapy [22], antiviral activity against human immunodeficiency virus [23], DNA photocleavage [24], antioxidant activity [25] and enzyme inhibition [26]. The fullerene derivatives incorporating a pendant-protected amino acid moiety, such as the phenylalanine derivative (Fig. 2), inhibits CA isozymes [27]. The use of nanomaterials to diagnose and treat disease has been a goal ever since the advent of methods to manipulate molecules at the nanometer level. The interesting properties of fullerenes offer possibilities of utilizing them in biology and medicinal chemistry and promise a bright future for fullerenes as medicinal agents [28-30].

The results of recent studies indicate that a large number of CA isozymes were inhibited by fullerenes derivatives $[27,31]$. These compounds have been chosen to be investigated for their interactions with CAs because of the presence of polar moieties in the molecules of derivatized fullerenes, such as the hydroxy, amino, or carboxy ones, leads to enhanced water solubility, since main limitation of fullerene-based derivatives is constituted just by their poor water solubility [32-35].

The most potent inhibitors used in applications still present a primary sulfonamide group on a benzenoic or heterocyclic structure with anticonvulsant, antiurolithic, antiglaucoma, and anticancer properties that binds to the zinc ion through the deprotonated nitrogen atom [16]. However, despite the availability of several drugs, only $75 \%$ of the epileptic population significantly benefits from the current pharmacotherapy. Thus, the search for less toxic, more efficacious agents for the treatment of seizure disorders has been continued. 
In our previous work the complexation between six inhibitors of carbonic anhydrase enzyme including topiramate and its derivatives and analogues, has been studied extensively using QM calculations [36]. In the present study, we use the quantum mechanical calculations to investigate the binding of a fullerene derivative as a new nanoscale inhibitor from three different possible positions, 1:N5, 2:N13 and 3:O12, Fig. 2, to the active site of CA enzyme. Interaction energies, electronic states, deprotonation enthalpy (DE) of inhibitor, and complexation energy for three different complexes have been determined. In addition, calculated results have been compared with our previous results.

It should be mentioned that this distinctive feature of the CA active site architecture and details of CA-fullerene derivative complex structure is little understood at present. Determination of the energies and relative orientations of the active site of $\mathrm{CA}$ and inhibitor in CA-inhibitor complex using high-level calculations will contribute to advance our knowledge on the mechanism of inhibitors action. It should be mentioned that this.

\section{COMPUTATIONAL DETAILS}

Computational method. Ab initio calculations were carried out with the Gaussian program series 1998 [37]. The geometries of carbonic anhydrase enzyme active site (CA), inhibitor and its related anion, the complex between inhibitors and CA were fully optimized employing Becke-style 3-parameter [38] of density functional theory (DFT) [39] with the standard $6-31 \mathrm{G}^{*}$ basis set. Full optimizations have been performed without any symmetry constrains. The harmonic vibrational frequencies were computed to confirm that an optimized geometry correctly corresponds to a local minimum that has only real frequencies. In addition, the thermodynamic properties of all compounds were obtained from frequency calculations at $298.15 \mathrm{~K}$ and 1.0 atmosphere pressure. All reported enthalpies were zero-point (ZPE) corrected with unscaled frequencies. For the equilibrium geometries of the CA/Inh complexes, B3LYP single point calculations with the 6-311G** basis set were performed for the B3LYP/6-31G* optimized complexes.

Calculation of binding energy. To quantify the interaction between inhibitor and CA active site in the optimized geometries, the binding energy (BE) and complexation energy (CE) are evaluated using the equation (2) and (3) [40]:

$$
\begin{aligned}
& \mathrm{BE}=E_{\mathrm{CA} / \text { Inh }}-\left(E_{\text {isolated CA }}+E_{\text {isolated Inh }}\right), \\
& \mathrm{CE}=E_{\text {opt complex }}-\left(E_{\text {opt CA }}+E_{\text {opt Inh }}\right) .
\end{aligned}
$$

According the equation (2), the complexation energy is defined as the difference between the energies of isolated inhibitor and the CA active site, at their optimized conformations, and that of the complex.

\section{RESULT AND DISCUSSION}

Geometry optimization of carbonic anhydrase active center. Structure of carbonic anhydrase active center was fully optimized at B3LYP methods using 6-31G* basis set with no initial symmetry restrictions and assuming $C_{1}$ point group. Fig. 3 shows the optimized structure and some structural details of carbonic anhydrase active center. As Fig. 3 indicates, the average $\mathrm{N}(\mathrm{His})-\mathrm{Zn}-\mathrm{O}\left(\mathrm{OH}_{2}\right)$ and $\mathrm{N}(\mathrm{His})-\mathrm{Zn}-\mathrm{N}(\mathrm{His})$ bond angles are equal to $92.3^{\circ}$ and $119.74^{\circ}$ respectively.

Nano scale inhibitor of fullerene and related anions. Geometry optimization. The geometry of nano scale inhibitor, Fig. 2, has been fully optimized using B3LYP/6-31G* method. Fig. 4 shows the optimized geometry of the inhibitor, and Table 1 indicates some chemical structure of optimized inhibitor.

According to eq. (1), the anionic form of inhibitor binds to the $\mathrm{Zn}^{2+}$ ion to form the complex between active center of CA enzyme and inhibitor, so in the next step the different anionic forms of the inhibitor have been constructed by detaching the proton from N5, N13 and O12 positions, and then optimized at the same level of computation. Fig. 5 shows the optimized geometry. Table 2 shows some structural details. Comparison between calculated results in Table 1 and Table 2

shows that the C4-N5 and N5-C6 bond lengths decrease from $1.46 \AA$ and $1.39 \AA$, respectively, in the real molecule, to $1.43 \AA$ and $1.33 \AA$ in the anion 1 (Table 2); the C9-N13 and N13-C14 bond lengths decrease from $1.46 \AA$ and $1.35 \AA$, respectively, to $1.45 \AA$ and $1.31 \AA$ in the anion 2 , and $\mathrm{C} 10-\mathrm{O} 12$ bond length decreases from $1.34 \AA$ to $1.26 \AA$ in the anion 3 . 
All these differences are consistent with a decrease in bonding and delocalization of the negative charge in the anion.

Calculation of deprotonation enthalpy (DE) of inhibitor. Total enthalpies of the species $\mathrm{X}, H(\mathrm{X})$, at the temperature $T$ are from the equation (4) [41-43]

$$
H(\mathrm{X})=E_{0}+\mathrm{ZPE}+E_{\text {trans }}+E_{\mathrm{rot}}+E_{\mathrm{vib}}+R T .
$$

Where $E_{0}$ is the calculated total electronic energy; ZEP stands for zero-point energy; $E_{\text {trans }}, E_{\text {rot }}, E_{\text {vib }}$ are the translational, rotational, and vibrational contributions to the enthalpy, respectively. Finally, $R T$ represents PV-work term and is added to convert the energy to enthalpy.

The deprotonation enthalpy (DE) is equal to $\mathrm{DE}=H_{\mathrm{a}}+H_{\mathrm{p}}-H_{\mathrm{ih}}$, where $H_{\mathrm{a}}$ is the enthalpy of the anion generated by proton-abstraction, $H_{\mathrm{p}}$ is the enthalpy of proton and $H_{\mathrm{ih}}$ is the enthalpy of the inhibitor.

Table 3 shows the calculated DE values for three anions formed by proton abstraction from inhibitor. According to data in Table 3, deprotonation of inhibitor from three positions is endothermic. The results show the following DE sequence for three anions in B3LYP level: $\mathrm{O} 12<\mathrm{N} 5 \leq \mathrm{N} 13$.

According to the resent study [27] on the fullerenes, these compounds have been chosen for interactions with CAs for two resons: 1) the polar moieties in the molecules of fullerene derivatives, leads to enhanced water solubility of these

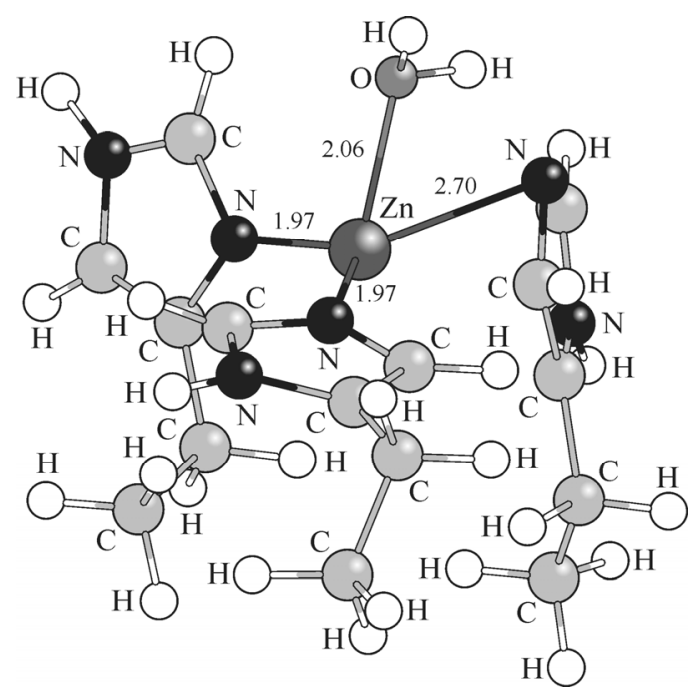

Fig. 3. Optimized structure of carbonic anhydrase enzyme in gas phase; the average bond angle $\mathrm{N}-\mathrm{Zn}-\mathrm{N}$ is $119.74^{\circ}$, the average bond angle $\mathrm{N}-\mathrm{Zn}-\mathrm{O}$ is $92.32^{\circ}$.

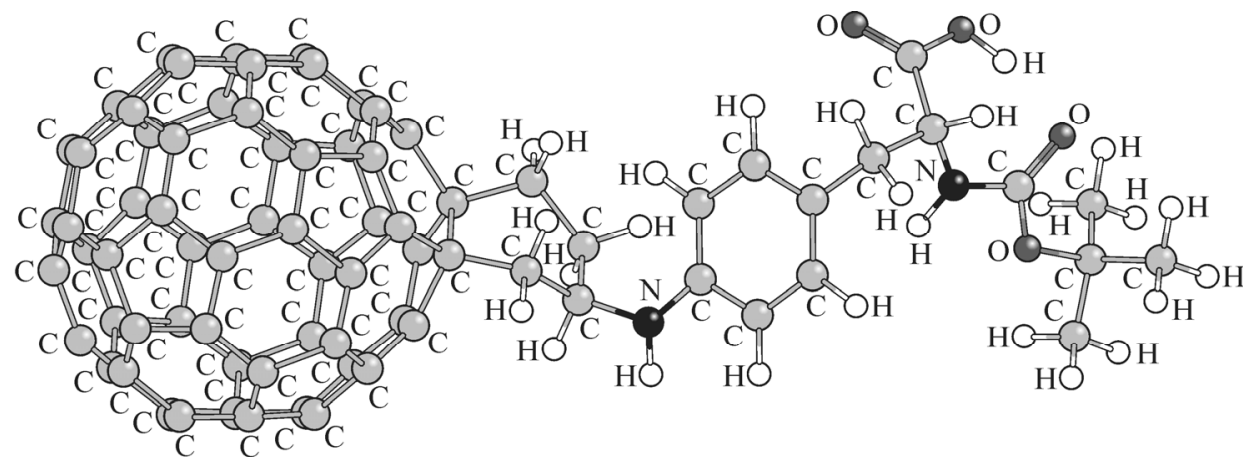

Fig. 4. Optimized structure of the inhibitor $\mathrm{C}_{60}-$ Inh in gas phase. 
TABLE 1. Presentation of Some Structural Parameters of Optimized Nanoscale Inhibitor

\begin{tabular}{|c|c|c|c|c|c|}
\hline Connected atom & Inhibitor & Connected atom & Inhibitor & Connected atom & Inhibitor \\
\hline \multicolumn{2}{|c|}{ Bond distance, $\AA$} & \multicolumn{2}{|c|}{ Bond angle, deg } & \multicolumn{2}{|c|}{ Dihedral bond, deg } \\
\hline $\mathrm{C} 1-\mathrm{C} 2$ & 1.64 & $\mathrm{C} 1-\mathrm{C} 2-\mathrm{C} 3$ & 110.90 & $\mathrm{C} 1-\mathrm{C} 2-\mathrm{C} 3-\mathrm{C} 4$ & -53.07 \\
\hline C4-N5 & 1.46 & C4-N5-C6 & 127.58 & $\mathrm{C} 3-\mathrm{C} 4-\mathrm{N} 5-\mathrm{C} 6$ & -60.58 \\
\hline N5-C6 & 1.39 & C9-C10-O12 & 115.00 & $\mathrm{C} 7-\mathrm{C} 8-\mathrm{C} 9-\mathrm{N} 13$ & -44.79 \\
\hline $\mathrm{C} 9-\mathrm{C} 10$ & 1.55 & $\mathrm{O} 11-\mathrm{C} 10-\mathrm{O} 12$ & 121.53 & $\mathrm{C} 8-\mathrm{C} 9-\mathrm{C} 10-\mathrm{O} 12$ & 179.94 \\
\hline $\mathrm{C} 10-\mathrm{O} 12$ & 1.34 & C9-N13-C14 & 123.45 & O12-C10-C9-N13 & -54.67 \\
\hline C9-N13 & 1.46 & $\mathrm{~N} 13-\mathrm{C} 14-\mathrm{O} 16$ & 111.00 & C8-C9-N13-C14 & -156.11 \\
\hline N13-C14 & 1.35 & C8-C9-N13 & 110.13 & C10-C9-N13-C14 & 77.08 \\
\hline & & & & C9-N13-C14-O16 & 170.84 \\
\hline
\end{tabular}

TABLE 2. Selected Structural Parameter Details of Optimized Deprotonated Inhibitor from Three Positions; 1: N5, 2: N13, 3: O12

\begin{tabular}{|c|c|c|c|c|c|c|c|}
\hline Connected atom & N5 & N13 & $\mathrm{O} 12$ & Connected atom & N5 & N13 & $\mathrm{O} 12$ \\
\hline \multicolumn{4}{|c|}{ Bond distance, $\AA$} & \multicolumn{4}{|c|}{ Bond angle, deg } \\
\hline $\mathrm{C} 1-\mathrm{C} 2$ & 1.64 & 1.64 & 1.64 & $\mathrm{C} 1-\mathrm{C} 2-\mathrm{C} 3$ & 111.14 & 111.06 & 110.71 \\
\hline C4-N5 & 1.44 & 1.46 & 1.48 & C4-N5-C6 & 123.00 & 125.84 & 118.93 \\
\hline N5-C6 & 1.34 & 1.41 & 1.43 & $\mathrm{C} 9-\mathrm{C} 10-\mathrm{O} 12$ & 114.96 & 114.86 & 115.22 \\
\hline $\mathrm{C} 9-\mathrm{C} 10$ & 1.55 & 1.56 & 1.59 & $\mathrm{O} 11-\mathrm{C} 10-\mathrm{O} 12$ & 121.28 & 121.41 & 130.05 \\
\hline $\mathrm{C} 10-\mathrm{O} 12$ & 1.34 & 1.33 & 1.26 & C9-N13-C14 & 124.02 & 116.22 & 126.19 \\
\hline C9-N13 & 1.46 & 1.45 & 1.45 & N13-C14-O16 & 111.05 & 111.45 & 109.55 \\
\hline $\mathrm{N} 13-\mathrm{C} 14$ & 1.35 & 1.31 & 1.34 & C8-C9-N13 & 109.72 & 109.68 & 114.29 \\
\hline \multicolumn{8}{|c|}{ Dihedral bond, deg } \\
\hline $\mathrm{C} 1-\mathrm{C} 2-\mathrm{C} 3-\mathrm{C} 4$ & -53.55 & -52.84 & -53.92 & $\mathrm{O} 12-\mathrm{C} 10-\mathrm{C} 9-\mathrm{N} 13$ & -53.79 & -56.88 & -7.60 \\
\hline $\mathrm{C} 3-\mathrm{C} 4-\mathrm{N} 5-\mathrm{C} 6$ & -78.02 & -85.26 & -79.59 & C8-C9-N13-C14 & -157.09 & -159.36 & -63.34 \\
\hline C7-C8-C9-N13 & -39.58 & -57.43 & -56.35 & C10-C9-N13-C14 & 76.33 & 74.97 & 172.38 \\
\hline $\mathrm{C} 8-\mathrm{C} 9-\mathrm{C} 10-\mathrm{O} 12$ & -178.69 & 177.95 & -133.33 & C9-N13-C14-O16 & 171.01 & 170.01 & -173.43 \\
\hline
\end{tabular}

TABLE 3. Calculated Deprotonation Enthalpy (DE) for Inhibitor from Three Positions; $1:$ N5, 2: N13, 3: O12 by Using B3LYP/6-31G* Method

\begin{tabular}{c|c}
\hline Anion position & DE, kcal/mol \\
\hline N5 & 352.75 \\
N13 & 353.75 \\
O12 & 342.31
\end{tabular}

$$
\mathrm{DE}=\left(H_{\mathrm{an}}+H_{\mathrm{H}}^{+}\right)-\left(H_{\mathrm{In}}\right)
$$

compounds. 2) The same moieties were shown to interact with amino acid residues at the entrance of the carbonic anhydrase active center cavity, in classical carbonic CA inhibitors such as topiramate. It should be stressed that many amino acids such as histidine 64, contribute extensively in proton transferring in such inhibitors [27] or the CA activators [44]. However, in the present study, because of big size of nanoscale inhibitor and using the high level of QM calculations we could not show the role of amino acids in proton transferring that lead to reduce the huge value of DE in our used model system.

DFT calculations for complexes between carbonic anhydrase active center and nano scale inhibitor. In the presence of deprotonated inhibitor, an enzyme-inhibitor complex forms, reaction 1. To follow the complexation process employing scan procedure the potential energy variations have been obtained using B3LYP/6-31G* method, while the 1578 
TABLE 4. Calculated Complexation Energy for Three Complexes; [CA-C60-Inh(N5)] $]^{+}$, $\left.\mathrm{CA}-\mathrm{C} 60-\mathrm{Inh}(\mathrm{N} 13)\right]^{+}$and $[\mathrm{CA}-$ C60-Inhi(O12) $]^{+}$by Using B3LYP/6-31G* and B3LYP/6-311G** Methods

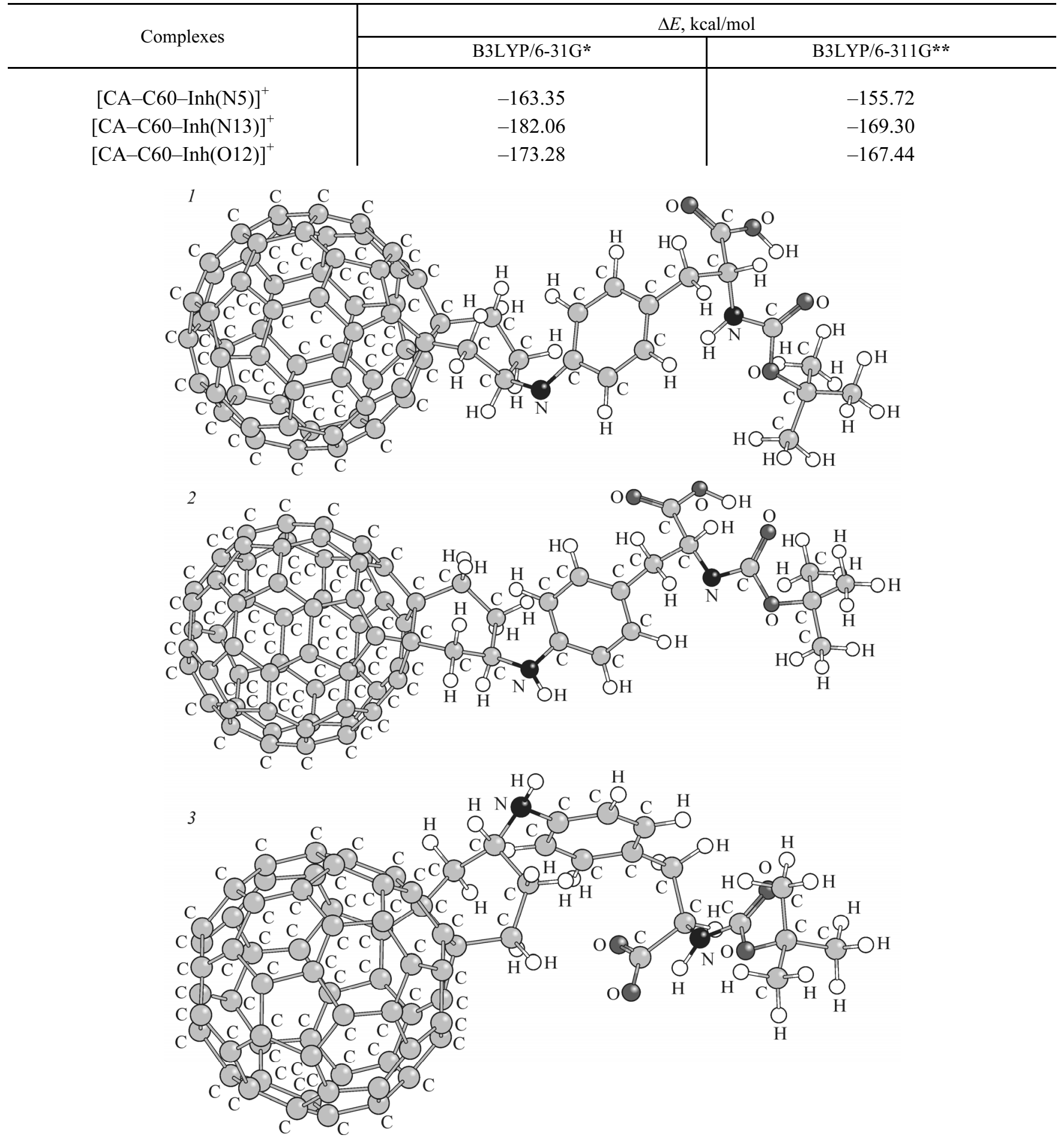

Fig. 5. Optimized structure of deprotonated inhibitor from three positions: N5 (1), N13 (2), O12 (3).

distance between N5, O12 and N13 atoms in inhibitor and $\mathrm{Zn}^{2+}$, as a proper reaction coordinate, was decreased from $5 \AA$ in step of $0.3 \AA$. The binding energy at different distances is presented in Fig. 6 . The negative BE change upon complexation 


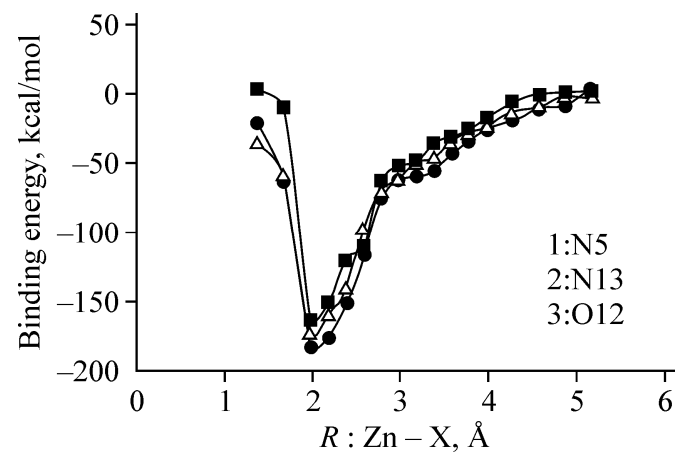

Fig. 6. The plot of bond distance $(\mathrm{Zn}-\mathrm{X}$; $\mathrm{X}=1: \mathrm{N} 5,2: \mathrm{N} 13,3: \mathrm{O} 12)$ versus binding energy (BD) by using keywords scan in B3LYP/6-31G* method.

clearly demonstrates that the $\mathrm{CA}$ active site can form stable complex with the nano scale inhibitor. Therefore, in the presence of the deprotonated inhibitor, an enzyme-inhibitor complex forms, reaction 1.

According to Fig. 6 the optimum distances between $\mathrm{Zn}^{2+}$ and N5, O12 and N13 atoms are $1.93 \AA, 2.01 \AA$ and $1.98 \AA$ respectively. To calculate the complexation energy, the geometry of the three complexes has been fully optimized at the Zn-X (X: N5, O12 and N13 atoms) optimum distance, Fig. 7. The computed complexation energy for the various complexes is reported in Table 4.

As the results in Table 4 indicate, substitution of the anionic form of inhibitor in the place of water molecule at the active center of CA enzyme is energetically exothermic, and binding of the inhibitor from N13 atom to the active center of $\mathrm{CA}$ is more favorable energetically. For the equilibrium geometries of the CA-Inh complexes, B3LYP/6-311G** single point calculations were performed. The results of recent calculations confirm that the CA-C60-Inh(N13) complex is about 2 and $13.5 \mathrm{kcal} / \mathrm{mol}$ more stable than $\mathrm{CA}-\mathrm{C} 60-\mathrm{Inh}(\mathrm{O} 12)$ and CA-C60-Inh(N5) respectively.

Optimized geometry indicates that all complexes have tetrahedral geometry. Table 5 shows some structural details of these complexes according to the numbering in Fig. 8.

A comparison of some structural details of three complexes with the native active center of CA indicates that a significant conformational rearrangement is necessary in the active site in order to allow the binding of the inhibitor. This fact has never been evidenced in CA-inhibitor adducts before, as the active site of this protein is a highly rigid one [45]. For example, according to Table 5, at the B3LYP level the average bond angle between nitrogen atoms of histidine and zinc, $\mathrm{N}-$ $\mathrm{Zn}-\mathrm{N}$, is about $103^{\circ}$ rather than $119.74^{\circ}$ in $\mathrm{CA}-\mathrm{OH}_{2}$, and average bond angle $\mathrm{X}-\mathrm{Zn}-\mathrm{N}$ (His) is about $115^{\circ}$ (in complex 1 and 2) and $117^{\circ}$ (in complex 3) rather than $92.3^{\circ}$ for bond angle $\mathrm{O}(\mathrm{OH} 2)-\mathrm{Zn}-\mathrm{N}(\mathrm{His})$ angle in $\mathrm{CA}-\mathrm{OH}_{2}$. So, the inhibitor binding to the zinc ion generates a structure that closely approaches tetrahedral geometry.

Analysis of thermodynamic properties for three complexes. No experimental data of thermodynamic functions such as standard enthalpies of complexation $\left(\Delta H_{\mathrm{com}}^{0}\right)$ and the standard Gibbs free energies of complexation $\left(\Delta G_{\mathrm{com}}^{0}\right)$ for CAinhibitor complexes is available. Therefore $\Delta U_{\mathrm{com}}^{0}, \Delta H_{\mathrm{com}}^{0}, \Delta S_{\mathrm{com}}^{0}$ and $\Delta G_{\mathrm{com}}^{0}$ were calculated for [CA-C60-Inh(N5)] $]^{+},[\mathrm{CA}-$ $\mathrm{C} 60-\mathrm{Inh}(\mathrm{N} 13)]^{+}$and $[\mathrm{CA}-\mathrm{C} 60-\operatorname{Inhi}(\mathrm{O} 12)]^{+}$complexes. The standard enthalpy change of the complexation $\left(\Delta H_{\mathrm{com}}^{0}\right)$ is given as:

$$
\Delta H_{\mathrm{com}}^{0}=\left[H_{\text {complex }}^{0}+H_{\mathrm{H}_{2} \mathrm{O}}^{0}\right]-\left[H_{\mathrm{EZn}(\mathrm{II}) \mathrm{OH}_{2}}^{0}+H_{\text {inhibitor- }}^{0}\right] .
$$

The total standard enthalpies of the studied species, at the temperature $T$ are estimated from the expression (4).

Similarity, $\Delta S_{\mathrm{r}}^{0}$ could be obtained by

$$
\Delta S_{\mathrm{com}}^{0}=\left[S_{\text {complex }}^{0}+S_{\mathrm{H}_{2} \mathrm{O}}^{0}\right]-\left[S_{\mathrm{EZn(II)OH}}^{0}+S_{\text {inhibitor- }}^{0}\right] .
$$




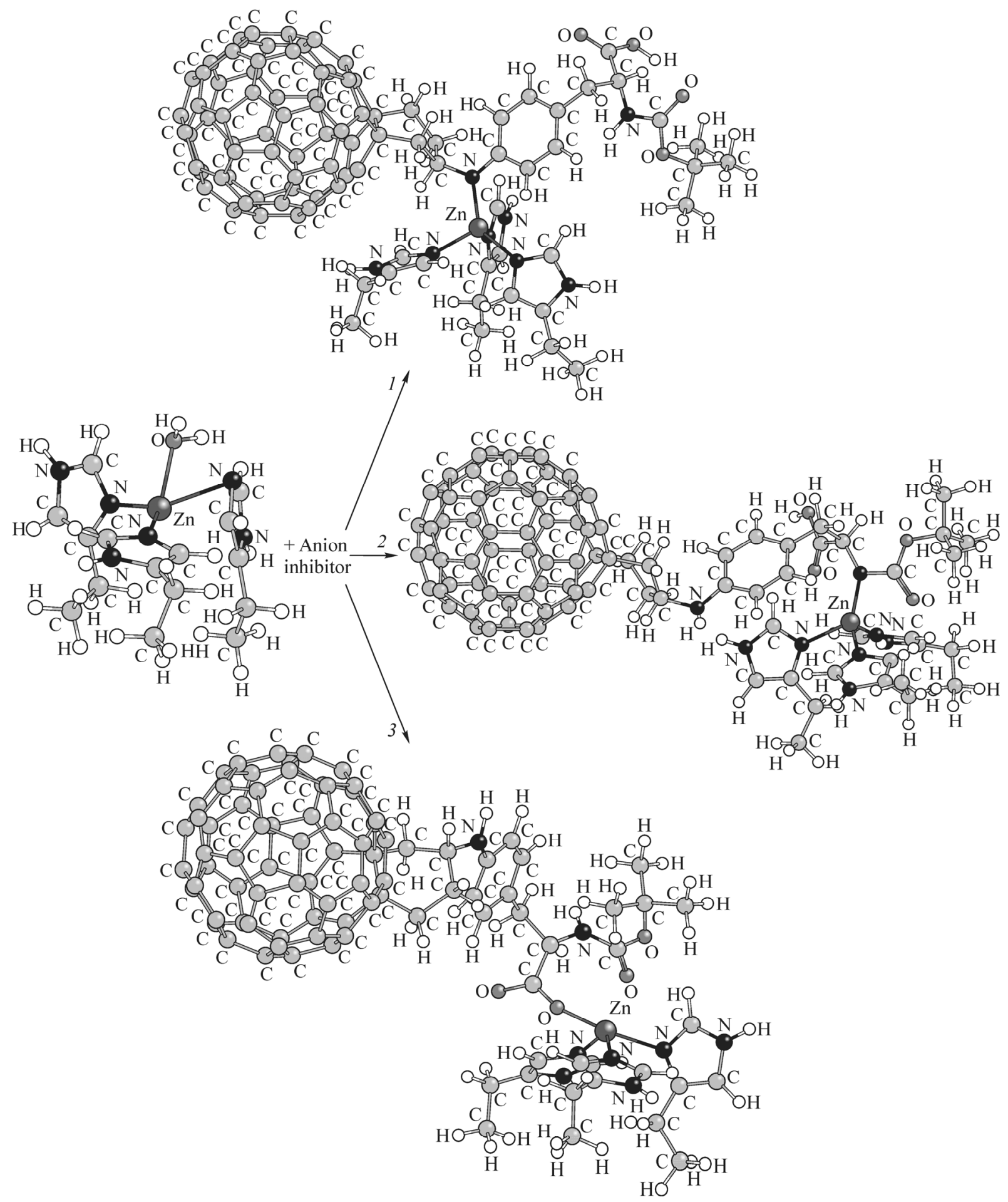

Fig. 7. Optimized geometry of complexes between $\mathrm{CA}$ active site and inhibitor from three positions: $[\mathrm{CA}-\mathrm{C} 60-\mathrm{Inh}(\mathrm{N} 5)]^{+}(1),[\mathrm{CA}-\mathrm{C} 60-\mathrm{Inh}(\mathrm{N} 13)]^{+}(2),[\mathrm{CA}-\mathrm{C} 60-\mathrm{Inh}(\mathrm{O} 12)]^{+}(3)$.

From the equation, $\Delta G=\Delta H-T \Delta S$, the $\Delta G_{\text {com }}^{0}$ was calculated. The computed thermodynamic properties for the various complexes are listed in Table 6. As the results in Table 6 indicate, substitution of the anionic form of inhibitor in place of water molecule at the active center of CA enzyme is energetically exothermic, and binding of the inhibitor from N13 atom to the active center of $\mathrm{CA}$ is more favorable energetically. It is noticeable that the entropy of formation for all the 
TABLE 5. Presentation of Some Structural Details for Three Complexes; 1: [CA-C60-Inh(N5)] , 2: [CA-C60-Inh(N13)] , 3: [CA-C60-Inh $(\mathrm{O} 12)]^{+}$by Using B3LYP/6-31G* Method

\begin{tabular}{|c|c|c|c|c|c|c|c|}
\hline Connected atom & 1 & 2 & 3 & Connected atom & 1 & 2 & 3 \\
\hline \multicolumn{8}{|c|}{ Bond distance, $\AA$} \\
\hline $\mathrm{C} 1-\mathrm{C} 2$ & 1.64 & 1.64 & 1.64 & $\mathrm{C} 9-\mathrm{C} 10$ & 1.55 & 1.52 & 1.56 \\
\hline C4-N5 & 1.47 & 1.48 & 1.47 & $\mathrm{C} 10-\mathrm{O} 12$ & 1.34 & 1.35 & 1.29 \\
\hline $\mathrm{X}-\mathrm{Zn}^{\mathrm{a}}$ & 1.93 & 1.98 & 2.01 & C9-N13 & 1.46 & 1.45 & 1.47 \\
\hline $\mathrm{Zn}-\mathrm{N}^{\mathrm{b}}$ & 2.07 & 2.08 & 2.11 & $\mathrm{~N} 13-\mathrm{C} 14$ & 1.35 & 1.35 & 1.33 \\
\hline N5-C6 & 1.39 & 1.41 & 1.39 & & & & \\
\hline \multicolumn{8}{|c|}{ Bond angle, deg } \\
\hline $\mathrm{C} 1-\mathrm{C} 2-\mathrm{C} 3$ & 110.98 & 110.88 & 110.90 & $\mathrm{C} 8-\mathrm{C} 9-\mathrm{C} 10$ & 112.89 & 111.50 & 113.46 \\
\hline C4-N5-C6 & 120.45 & 124.05 & 127.04 & C9-C10-O12 & 115.00 & 111.75 & 115.69 \\
\hline $\mathrm{X}-\mathrm{Zn}-\mathrm{N}$ & 115.01 & 115.33 & 117.38 & C9-N13-C14 & 123.41 & 118.37 & 124.20 \\
\hline $\mathrm{N}-\mathrm{Zn}-\mathrm{N}$ & 103.54 & 102.99 & 103.55 & C8-C9-N13 & 109.98 & 115.40 & 109.50 \\
\hline $\mathrm{A}-\mathrm{X}-\mathrm{Zn}^{\mathrm{c}}$ & 115.37 & 134.01 & 129.26 & $\mathrm{O} 11-\mathrm{C} 10-\mathrm{O} 12$ & 121.54 & 121.86 & 125.92 \\
\hline $\mathrm{B}-\mathrm{X}-\mathrm{Zn} \mathrm{n}^{\mathrm{d}}$ & 124.14 & 105.46 & - & & & & \\
\hline \multicolumn{8}{|c|}{ Dihedral angle, deg } \\
\hline $\mathrm{C} 1-\mathrm{C} 2-\mathrm{C} 3-\mathrm{C} 4$ & -52.75 & -52.68 & -53.12 & C9-N13-C14-O16 & 172.14 & 12.94 & -175.07 \\
\hline $\mathrm{C} 3-\mathrm{C} 4-\mathrm{N} 5-\mathrm{C} 6$ & -57.63 & -49.51 & -58.18 & $\mathrm{D}-\mathrm{X}-\mathrm{E}-\mathrm{Zn}^{\mathrm{e}}$ & -177.62 & -165.62 & - \\
\hline C7-C8-C9-N13 & -46.45 & -72.10 & -49.43 & $\mathrm{~F}-\mathrm{G}-\mathrm{X}-\mathrm{Zn}{ }^{\mathrm{f}}$ & 124.54 & -24.85 & -59.80 \\
\hline $\mathrm{C} 8-\mathrm{C} 9-\mathrm{C} 10-\mathrm{O} 12$ & 179.83 & 60.75 & -155.43 & $\mathrm{H}-\mathrm{X}-\mathrm{Zn}-\mathrm{N}^{\mathrm{g}}$ & -40.36 & -22.57 & -46.98 \\
\hline O12-C10-C9-N13 & -55.14 & -170.11 & -30.24 & $\mathrm{I}-\mathrm{X}-\mathrm{Zn}-\mathrm{N}^{\mathrm{h}}$ & 21.91 & 55.12 & - \\
\hline C8-C9-N13-C14 & -156.28 & -97.30 & -162.17 & $\mathrm{O} 11-\mathrm{C} 10-\mathrm{O} 12-\mathrm{Zn}$ & - & - & 116.51 \\
\hline C10-C9-N13-C14 & 77.09 & 135.71 & 70.51 & & & & \\
\hline
\end{tabular}

${ }^{\mathrm{a}} \mathrm{X}$ in complex 1 is N5, in complex 2 is N13 and complex 3 is $\mathrm{O} 12$.

${ }^{\mathrm{b}}$ Average Zn-N18, Zn-N19 and Zn-N20.

${ }^{\mathrm{c}} \mathrm{A}$ in complex 1 is $\mathrm{C} 4$, and complex 2 is $\mathrm{C} 9$ and complex 3 is $\mathrm{C} 10$.

${ }^{\mathrm{d}} \mathrm{B}$ in complex 1 is $\mathrm{C} 6$ and complex 2 is $\mathrm{C} 14$.

${ }^{\mathrm{e}} \mathrm{D}$ in complex 1 is $\mathrm{C} 4$ and $\mathrm{E}$ is $\mathrm{C} 6$, in complex $2 \mathrm{D}$ is $\mathrm{C} 9$ and $\mathrm{E}$ is $\mathrm{C} 14$.

${ }^{\mathrm{f}} \mathrm{F}$ in complex 1 is $\mathrm{C} 3$ and $\mathrm{G}$ is $\mathrm{C} 4$, in complex $2 \mathrm{~F}$ is $\mathrm{C} 10$ and $\mathrm{G}$ is $\mathrm{C} 9$ and in complex $3 \mathrm{~F}$ is $\mathrm{C} 9$ and $\mathrm{G}$ is $\mathrm{C} 10$.

${ }^{\mathrm{g}} \mathrm{H}$ in complex 1 is $\mathrm{C} 4$, in complex 2 is $\mathrm{C} 9$ and complex 3 is $\mathrm{C} 10$.

${ }^{\mathrm{h}} \mathrm{I}$ in complex 1 is $\mathrm{C} 6$, in complex 2 is $\mathrm{C} 14$.

complexes is negative. The more negative values of $\Delta H_{\mathrm{com}}^{0}$ and $\Delta G_{\mathrm{com}}^{0}$ are found for [CA-C60-Inh (N13) ] complex, and the less negative $\Delta H_{\mathrm{r}}^{0}$ and $\Delta G_{\mathrm{r}}^{0}$ values are found [CA-C60-Inh (N5) $]^{+}$.

Topiramate [46-48], sulfamate substituted monosaccharide: 2.3:4.5-Bis-O-(1-methylethylidene)- $\beta$-D-fructopyranose sulfamate, Fig. 9, is an anticonvulsant drug marketed worldwide for the treatment of epilepsy and prophylaxis of migraine. Topiramate binds to the zinc ion through the deprotonated nitrogen atom, [CA-Top)] $]^{+}$. Table 6 shows the thermodynamic functions of [CA-Top)] ${ }^{+}$complex according to our previous study [36]. A closer look to the data in Table 6 shows a good agreement between predicted thermodynamic properties of [CA-C60-Inh (N13) $]^{+}$and $\left.[\mathrm{CA}-\mathrm{Top})\right]^{+}$complexes. These data may be helpful in the design of carbonic anhydrase inhibitors with a potential as anti-obesity drugs or other pharmaceutical applications.

Details of atomic net charges of nanoscale inhibitor and three complexes. Calculated net atomic charges on the nanoscale inhibitor and three different complexes are presented in Table 7. These partial charges are derived from NBO (natural bond orbital) calculation. The net negative charge on the N13 atom is more than N5 and O12 atoms. An interesting point is the partial charge on zinc, which is worth mentioning. The net charge on the zinc is $0.92,0.93$ values changes that 


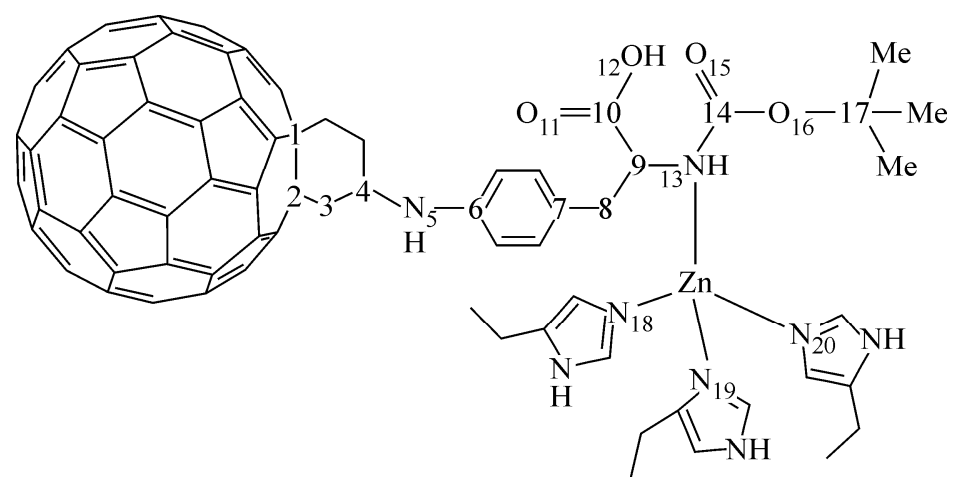

Fig. 8. Numbering of chemical structure for complex 2: $[\mathrm{CA}-\mathrm{C} 60-\operatorname{Inh}(\mathrm{N} 13)]^{+}$.<smiles>CC1(C)O[C@H]2OO[Te]3([IH]OOS(N)(=O)=O)OC(C)(C)O[C@H]3[Si]2O1</smiles>

Fig. 9. Chemical structure of topiramate.

TABLE 6. Calculated Thermodynamic Properties of $[\mathrm{CA}-\mathrm{C} 60-\mathrm{Inh}(\mathrm{N} 5)]^{+},[\mathrm{CA}-\mathrm{C} 60-\mathrm{Inh}(\mathrm{N} 13)]^{+}$and $[\mathrm{CA}-\mathrm{C} 60-\mathrm{Inh}(\mathrm{O} 12)]^{+}$ Complexes and Comparison with Calculated Thermodynamic Function of [CA-Top)] Complex According to Reference [36]

\begin{tabular}{c|c|c|c|c}
\hline Complexes & $\Delta U, \mathrm{kcal} / \mathrm{mol}$ & $\Delta H, \mathrm{kcal} / \mathrm{mol}$ & $\Delta S, \mathrm{cal} / \mathrm{mol}$ & $\Delta G, \mathrm{kcal} / \mathrm{mol}$ \\
\hline${\text { [CA-C60-Inh(N5) }]^{+}}^{+}$ & -163.35 & -162.76 & -6.81 & -160.72 \\
${[\mathrm{CA}-\mathrm{C} 60-\operatorname{Inh}(\mathrm{N} 13)]^{+}}_{[\mathrm{CA}-\mathrm{C} 60-\operatorname{Inh}(\mathrm{O} 12)]^{+}}^{-183.06}$ & -173.28 & -182.47 & -7.45 & -180.74 \\
$[\mathrm{CA}-\mathrm{Top})]^{+}[36]$ & -182.87 & -172.69 & -7.26 & -170.52 \\
\end{tabular}

TABLE 7. Selected Net Atomic Charges on Every Atom in Different Complexes 1: [CA-C60-Inh(N5)] ${ }^{+}, 2$ : [CA-C60Inh(N13) $]^{+}, 3:[\mathrm{CA}-\mathrm{C} 60-\operatorname{Inh}(\mathrm{O} 12)]^{+}$and Related Inhibitors Anion by Using B3LYP/6-31G* Method

\begin{tabular}{|c|c|c|c|c|c|c|c|}
\hline Atom & 1 & 2 & 3 & Atom & 1 & 2 & 3 \\
\hline \multicolumn{4}{|c|}{ Complex } & \multicolumn{4}{|c|}{ Anion } \\
\hline $\mathrm{Zn}$ & 0.93 & 0.92 & 0.96 & $\mathrm{C}_{4}$ & 0.04 & 0.06 & 0.03 \\
\hline $\mathrm{C}_{4}$ & 0.06 & 0.03 & 0.05 & $\mathrm{~N}_{5}$ & -0.65 & -0.74 & -0.60 \\
\hline $\mathrm{N}_{5}$ & -0.78 & -0.69 & -0.71 & $\mathrm{C}_{6}$ & 0.30 & 0.35 & 0.27 \\
\hline $\mathrm{C}_{6}$ & 0.38 & 0.31 & 0.40 & $\mathrm{C}_{9}$ & -0.07 & -0.09 & -0.03 \\
\hline $\mathrm{C}_{9}$ & -0.07 & -0.05 & -0.07 & $\mathrm{~N}_{13}$ & -0.62 & -0.78 & -0.62 \\
\hline $\mathrm{N}_{13}$ & -0.62 & -0.68 & -0.60 & $\mathrm{C}_{14}$ & 0.83 & 0.96 & 0.81 \\
\hline $\mathrm{C}_{14}$ & 0.84 & 0.84 & 0.88 & $\mathrm{C}_{10}$ & 0.63 & 0.80 & 0.58 \\
\hline $\mathrm{C}_{10}$ & 0.63 & 0.60 & 0.65 & $\mathrm{O}_{12}$ & -0.60 & -0.71 & -0.67 \\
\hline $\mathrm{O}_{12}$ & -0.61 & -0.56 & -0.66 & & & & \\
\hline $\mathrm{N}^{\mathrm{a}}$ & -0.57 & -0.56 & -0.57 & & & & \\
\hline
\end{tabular}

\footnotetext{
${ }^{\text {a }}$ Average $\mathrm{N}_{18}, \mathrm{~N}_{19}$ and $\mathrm{N}_{20}$.
} 
the $\mathrm{Zn}^{2+}$ ion is approximately reduced to $\mathrm{Zn}^{1+}$. By taking into account the charge of nanoscale inhibitor interacting atoms, $\mathrm{N} 13(-0.78)$, N5 (-0.65) and O12 (-0.67), a strong electrostatic bonding could be evidenced.

\section{CONCLUSIONS}

Ab initio calculations have been carried out in order to study the interaction between a derivative of fullerene as a nano scale inhibitor and active center of carbonic anhydrase. The inhibitor from three positions are tetrahedrally coordinated to the zinc ion of the enzyme via deprotonated nitrogen or oxygen atom in a hydrophobic pocket of the CA active center. This binding mechanism implies electrostatic $\mathrm{Zn}-\mathrm{X}(\mathrm{X}=\mathrm{N} 5$, N13 or O12) coordination. On this basis, the electronic distribution on the polar moiety in the pendant tails attached to the fullerene should correlate with the antiepileptic activity if this mechanism has any effect on the control of epilepsy. The results indicate that the $[\mathrm{CA}-\mathrm{C} 60-\mathrm{Inh}(\mathrm{N} 13)]^{+}$complex is the most favorable complex energetically. The molecule is a combination of a large, globular hydrophobic region and a small hydrophilic pendant tails. We suggest that the nature and disposition of these two segments are important for the biological activity. In addition, the fullerenes represent a totally new class of nanoscale carbonic anhydrase inhibitors that may find applications for targeting physiologically relevant isoforms.

The authors gratefully acknowledge financial support from the research council of Alzahra University. Also the authors would like to appreciate professor Claudiu T. Supuran for his advises for this work. Technical support of the Chemistry Computation Center at Shahid Beheshti University is greatly acknowledged.

\section{REFERENCES}

1. (a) S. Parkkila, A. K. Parkkila, and J. Kivela, in: Carbonic Anhydrase: Its Inhibitors and Activators, Eds. C. T. Supuran, A. Scozzafava and J. Conway, CRC Press: Boca Raton (2004), p. 283-301; (b) K. Kaila and B. Ransom, PH and Brain Function, Wiley-Liss, New-York (1998).

2. P. Halmi, S. Parkkila, and J. Honkaniemi, Neurochem. Int., 48, 24-30 (2006).

3. J. F. Domsic, B. S. Avvaru, C. U. Kim, et al., J. Biol. Chem., 283, 30766-30771 (2008).

4. (a) J. F. Ferry, Biochim. Biophys. Acta, 1804, 374-381 (2010); (b) K. S. Smith, C. Jakubzick, T. S. Whittam, et al., Proc. Natl. Acad. Sci., U.S.A. (1999), 96, 5184-15189; (c) S. A. Zimmerman, J. F. Tomb, and J. G. Ferry, J. Bacteriol., 192, 1353-1360 (2010); (d) S. A. Zimmerman, J. G. Ferry, and C. T. Supuran, Curr. Top. Med. Chem., 7, 901-908 (2007); (e) S. Elleuche and S. Pöggeler, Microbiology., 156, 23-29 (2010).

5. S. Lindskog, Pharmacol. Ther., 74, 1-20 (1997).

6. D. N. Silverman and S. Lindskog, Acc. Chem. Res., 21, 30-36 (1988).

7. A. Liljas, K. K. Kannan, P. C. Bergsten, et al., Nature, 235, 131-137 (1972).

8. S. K. Nair and D. W. Christianson, J. Am. Chem. Soc., 113, 9455-9458 (1991).

9. Z. Fisher, J. A. Hernandez Prada, C. Tu, et al., Biochemistry, 44, 1097-1105 (2005).

10. H. Steiner, B. H. Jonsson, and S. J. Lindskog, Eur. J. Biochem., 59, 253-259 (1975).

11. C. Tu, D. N. Silverman, C. Forsman, et al., Biochemistry, 28, 7913-7918 (1989).

12. D. Duda, C. Tu, M. Qian, et al., Biochemistry, 40, 1741-1748 (2001).

13. C. T. Supuran and A. Scozzafava, Bioorg. Med. Chem., 15, 4336-4350 (2007).

14. S. Pastorekova, S. Parkkila, J. Pastorek, et al., J. Enzyme Inhib. Med. Chem., 19, 199-229 (2004).

15. C. T. Supuran, Nat. Rev. Drug Disc., 7, 168-181 (2008).

16. (a) C. T. Supuran, Carbonic Anhydrases as Drug Targets-General Presentation. In: Drug Design of Zinc-Enzyme Inhibitors: Functional, Structural, and Disease Applications (C. T. Supuran., J. Y. Winum Eds.), Wiley: Hoboken (NJ) (2009), p. 15-38; (b) J. Y. Winum, M. Rami, A. Scozzafava, et al., Med. Res. Rev., 28, $445-463$ (2008); (c) C. T. 
Supuran, A. Scozzafava, and A. Casini, Med. Res. Rev., 23, 146-189 (2003); (d) J. F. Domsic, B. S. Avvaru, C. U. Kim, et al., J. Biol. Chem., 283, 30766-30771 (2008).

17. (a) C. T. Supuran, Curr. Pharm. Des., 14, 641-648 (2008); (b) C. T. Supuran, A. Di Fiore, and G. De Simone, Expert Opin. Emerg. Drugs., 13, 383-392 (2008); (c) G. De Simone, A. Di Fiore, and C. T. Supuran, Curr. Pharm. Des., 14, 655-660 (2008); (d) F. Mincione, A. Scozzafava, and C. T. Supuran, Antiglaucoma Carbonic Anhydrase Inhibitors as Ophthalmologic Drugs. In: Drug Design of Zinc-Enzyme Inhibitors: Functional, Structural, and Disease Applications (C. T. Supuran and J. Y. Winum Eds.), Wiley: Hoboken (NJ) (2009), p. 139-154; (e) J. Krungkrai and C. T. Supuran, Curr. Pharm. Des., 14, 631-640 (2008); (f) J. Borras, A. Scozzafava, L. Menabuoni, et al., Bioorg. Med. Chem., 7, 2397-2406 (1999).

18. (a) I. Nishimori, S. Onishi, H. Takeuchi, et al., Curr. Pharm. Des., 14, 622-630 (2008); (b) C. Schlicker, R. A. Hall, D. Vullo, et al., J. Mol. Biol., 385, 1207-1220 (2009); (c) S. Isik, F. Kockar, M. Aydin, et al., Bioorg. Med. Chem., 17, 1158-1163 (2009); (d) F. Carta, A. Maresca, A. Suarez Covarrubias, et al., Bioorg. Med. Chem. Lett., 19, 6649-6654 (2009).

19. (a) B. W. Clare and C. T. Supuran, J. Pharm. Sci., 83, 768-773 (1994); (b) C. Temperini, D. Vullo, A. Scozzafava, et al., J. Med. Chem., 49, 3019-3027 (2006).

20. A. V. Luzanov, J. Struct. Chem., 43, 1-9 (2002).

21. V. N. Ivanova, J. Struct. Chem., 41, 135-148 (2000).

22. Y. Tabata and Y. Ikada, Pure Appl. Chem., 71, 2047-2053 (1999).

23. S. H. Friedman, D. L. De Camp, R. P. Sijbesma, et al., J. Am. Chem. Soc., 115, 6506-6509 (1993).

24. H. Tokuyama, S. Yamago, E. Nakamura, et al., J. Am. Chem. Soc., 5, 7918/7919 (1993).

25. I. Wang, I. L. Tai, D. Lee, et al., J. Med. Chem., 42, 4614-4620 (1999).

26. S. T. Yang, H. F. Wang, L. Guo, et al., Nanotechnology, 19, 395101-395108 (2008).

27. A. Innocenti, S. Durdagi, N. Doostdar, et al., Bioorg. Med. Chem., 18, 2822-2828 (2010).

28. S. R. Wilson, D. I. Schuster, B. Nuber, et al., Fullerenes: Chemistry, Physics, and Technology (K. Kadish and R. Ruoff Eds.), John Wiley \& Sons, New-York (2000).

29. W. Kratschmer, L. D. Lamb, and D. R. Hoffman, Nature, 347, 354-358 (1990).

30. S. Yamago, H. Tokuyama, E. Nakamura, et al., Chem. Biol., 2, 385-389 (1995).

31. C. T. Supuran, Bioorg. Med. Chem. Lett., 20, 3467-3474 (2010).

32. (a) S. Bosi, T. Da Ros, G. Spalluto, et al., Eur. J. Med. Chem., 38, 913-923 (2003); (b) D. Pantarotto, N. Tagmatarchis, A. Bianco, et al., Mini-Rev. Med. Chem., 4, 805-814 (2004); (c) L. Sanchez, R. Otero, J. M. Gallego, et al., Chem. Rev., 109, 2081-2091 (2009).

33. (a) B. Kang, D. Yu, Y. Dai, et al., Small., 5, 1292-1301 (2009); (b) P. Chaudhuri, A. Paraskar, S. Soni, et al., ACS. Nano., 3, 2505-2014 (2009); (c) P. Mroz, G. P. Tegos, H. Gali, et al., Photochem. Photobiol. Sci., 6, 1139-1149 (2007).

34. (a) K. Yudoh, R. Karasawa, K. Masuko, et al., Int. J. Nanomed., 4, 217-225 (2009); (b) R. Partha and J. L. Conyers, Int. J. Nanomed., 4, 261-275 (2009); (c) K. Yudoh, K. Shishido, H. Murayama, et al., Arthritis Rheum., 56, 3307-3318 (2007).

35. (a) J. Yang and A. R. Barron, Chem. Commun., 21, 2884/2885 (2004); (b) J. Yang, L. B. Alemany, and J. Driver, Chem. Eur. J., 13, 2530-2545 (2007); (c) J. Yang, K. Wang, J. Driver, et al., Org. Biomol. Chem., 5, 260-266 (2007).

36. M. Ghiasi, S. Kamalinahad, M. Arabieh, and M. Zahedi, Comput. Theo. Chem., 992, 59-69 (2012).

37. M. J. Frisch, G. W. Trucks, H. B. Schlegel, et al., Gaussian 2003 (Revision-B), Gaussian, Inc., Pittsburgh PA (2003).

38. A. D. Beck, J. Chem. Phys., 98, 5648-5652 (1993).

39. R. G. Parr and W. Yang, Density-functional theory of atoms and molecules, Oxford Univ. Press (1989).

40. D. J. Barbiric, E. A. Castro, and R. H. de Rossi, J. Mol. Struct: Theochem., 532, 171-181 (2000). 
41. M. Navarrete, C. J. C. Rangel, and J. Corchado, J. Phys. Chem. A, 109, 4777-4784 (2005).

42. A. K. Chandra and T. Uchimaru, Int. J. Mol. Sci., 3, 407-422 (2002).

43. H. Y. Zhang and H. F. Ji, J. Mol. Struct: Theochem., 663, 167-174 (2003).

44. M. Ghiasi, M. Taheri, and M. Zahedi, Comp. Theo. Chem., 1022, 121-129 (2013).

45. A. Casini, J. Antel, F. Abbate, et al., Bioorg. Med. Chem. Lett., 13, 841-845 (2003).

46. M. Bialer, S. I. Johannessen, H. J. Kupferberg, R. H. Levey, P. Loiseau, and E. Perucca, Epilepsy Res., 43, 11-58 (2001).

47. J. L. Stringer, Epilepsy Res., 40, 147-153 (2000).

48. A. Sabers and L. Gram, Drugs., 60, 23-33 (2000). 